\title{
A 48-year-old female presented with severe neck pain
}

\author{
Mohammad Mizanur Rahman, Susane Giti, Md. Monirul Islam, Mohammad Shahidul Islam, \\ Mreenal Kanti Sarkar, Abdullah Al Maruf and Morshed Rashid
}

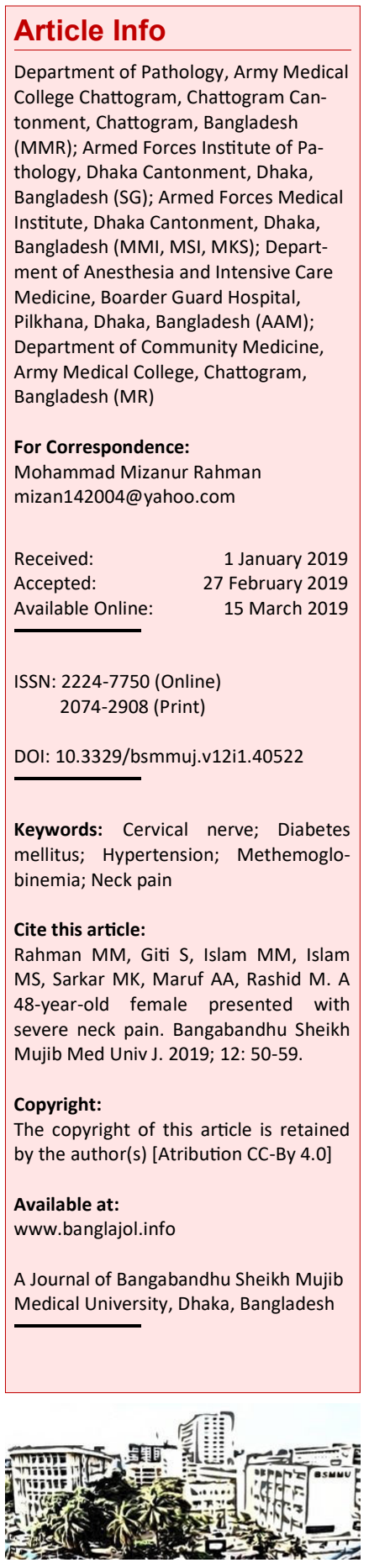

\section{Presentation of Case}

Dr. Md. Monirul Islam (Hematology resident): A 48-year-old married female got admitted on $8^{\text {th }}$ September 2017 into the Boarder Guard Hospital, Pilkhana, Dhaka, Bangladesh with the complaints of severe neck pain associated with low grade backache for the last four years. This patient is hailing from Soliabazar, Jashore, Southwestern region of Bangladesh where she was treated with local doctors by cervical collar and analgesics for her neck and back pain. As the pain did not subside, so she was brought by her brother-in-law who is a BGB soldier to Boarder Guard hospital for better management. The patient reported to the emergency and casualty department of the hospital where the attending medical officer took relevant history, performed physical examination and advised for few investigations.

On general examination, she was looking ill, pulse rate was $86 / \mathrm{min}$ and blood pressure was $140 / 90 \mathrm{~mm}$ of $\mathrm{Hg}$. No other abnormality was detected on general examination. No abnormality was found in the examination of cardiovascular, respiratory and gastrointestinal system. But nervous system examination revealed spastic gait and bilateral equivocal planter reflex. Tenderness and restriction of the neck movement were found on examination of the musculoskeletal system. Initial routine investigations revealed almost normal laboratory findings (Table I) except cardiomegaly on X-ray chest.

As the patient was complaining severe neck pain, so she was referred to the neurosurgeon. However, on the basis of history, clinical and physical findings I made a provisional diagnosis.

\section{Provisional Diagnosis}

Cervical nerve root compression with hypertension with diabetes mellitus

Dr. Rukun Udding Chowdhury (Neurosurgeon): I received the patient as a referral case on $12^{\text {th }}$ September 2017 in Combined Military Hospital, Dhaka from BGB hospital. I have critically reviewed the patient, performed physical examination and analyze the investigation results so far done. On physical examination I got all the features of rediculopathy. Therefore, on the basis of history, clinical and physical findings as well as investigation results, my initial impression was cervical spondylosis with lumbar spondylosis. I recommended for MRI cervical spine and echocardiography. After one week, patient was again sent to me with MRI and echocardiography report. MRI of the cervical spine showed degenerative disc and spine disease, central and paracentral disc protrusion causing thecal indentation, lateral recess, foraminal narrowing and bilateral traversing C5 and C6 nerve roots compressing at C4 - 5 and C5 - 6 levels. Echocardiography was normal. With this diagnosis I briefed the patient and her family members and decided to operate the patient by discectomy C4 - 5, corpectomy $\mathrm{C} 6$, reconstruction with cage/bone graft and anterior plate fixation. For preoperative assessment and fitness for anesthesia I referred the case to the anesthesiologist.

Dr. Abdullah Al Maruf (Anesthesiologist): This patient was sent to me on $16^{\text {th }}$ September 2017 at 1300 hours for pre-operative check-up. I reviewed the case and gone through all investigations. Results of all investigations were within the reference range. However, during talking with the patient I came to know that she underwent total abdominal hysterectomy few years back when the operating gynecologist told her that her blood is bluish (as per patient's language). Then I did the physical examination more meticulously and took detailed family history. I found that both central and peripheral cyanosis is present on general examination but there was no dyspnoea or palpitation or respiratory distress as well as examination of cardiovascular and respiratory system also did not reveal any abnormalities. The patient also told that her daughter and other children have the same problem. As her daughter was present at that time, so I also examined her and found cyanosis in the tongue, lips and hands. She also had no respiratory embarrassment. Figure 1 shows the cyanotic hands of the patient and her daughter. Getting such findings I advised to do arterial blood gas (ABG) analysis and pulse 


\begin{tabular}{|c|c|c|}
\hline \multicolumn{3}{|c|}{ Table I } \\
\hline \multicolumn{3}{|c|}{ Laboratory data } \\
\hline Variable & $\begin{array}{r}\text { Reference range, } \\
\text { Female } \emptyset\end{array}$ & Patients' data \\
\hline Hemoglobin $(\mathrm{g} / \mathrm{dL})$ & $12.0-15.0$ & 12.0 \\
\hline ESR ( $\mathrm{mm}$ in $1^{\text {st }}$ hour) & $0-20$ & 17 \\
\hline Hematocrit (L/L) & $0.35-0.46$ & 0.41 \\
\hline $\operatorname{RBC}\left(x 10^{12} / \mathrm{L}\right)$ & $3.8-4.8$ & 4.5 \\
\hline White cell count $\left(\times 10^{9} / \mathrm{L}\right)$ & $4.0-10.0$ & 9.5 \\
\hline \multicolumn{3}{|l|}{ Differential count $(\%)$} \\
\hline Neutrophils & $40-80$ & 52 \\
\hline Lymphocytes & $20-40$ & 45 \\
\hline Monocytes & $2-10$ & 02 \\
\hline Eosinophils & $1-6$ & 01 \\
\hline Basophils & $0.02-1$ & 00 \\
\hline Atypical cells & 0 & 00 \\
\hline Platelet count $\left(x 10^{9} / \mathrm{L}\right)$ & $150-410$ & 198 \\
\hline Peripheral blood film & & Non-specific findings \\
\hline G-6-PD (U/g Hb) & $6.97-20.5$ & 8.94 \\
\hline Serum LDH (U/L) & $225-480$ & 147 \\
\hline Blood group & & B positive \\
\hline Liver function tests & & Normal \\
\hline Renal function tests & & Normal \\
\hline Fasting plasma sugar (mmol/L) & & 5.1 \\
\hline $\begin{array}{l}\text { Plasma glucose } 2 \text { hours after break- } \\
\text { fast }(\mathrm{mmol} / \mathrm{L})\end{array}$ & & 6.0 \\
\hline Urine $\mathrm{R} / \mathrm{M} / \mathrm{E}$ & & Normal \\
\hline Serum electrolytes & & Normal \\
\hline Serum calcium & & Normal \\
\hline CXR (P/A view) & & Cardiomegaly \\
\hline MRI - Cervical spine & & $\begin{array}{l}\text { Degenerative disc } \\
\text { and spine disease }\end{array}$ \\
\hline ECG & & Normal \\
\hline \multicolumn{3}{|c|}{$\begin{array}{l}\text { I Reference values are affected by many variables, including the demographics } \\
\text { and the laboratory methods used. The ranges used at Armed Forces Institute of } \\
\text { Pathology are for adults who are not pregnant and do not have medical condi- } \\
\text { tions that could affect the results. They may, therefore, not be appropriate for } \\
\text { all patients }\end{array}$} \\
\hline
\end{tabular}

oxymetry. Though ABG result was within normal limit but pulse oxymetry showed $55 \% \mathrm{O}_{2}$ saturation. On the basis of such finding I thought that it might be a case of hemoglobinopathy. Therefore, I postponed the operation and referred the case to medical specialist.

Dr. Mohammad Sarwar Khan (Medical Specialist): I attended the patient on $16^{\text {th }}$ September at 2200 hours. I took detailed history and performed the physical examination. I found cyanosis (central and peripheral) on general examination and no abnormality was detected on systemic examination. Then I critically reviewed the case sheet and concluded my impression as a case of inherited hemoglobin disorder as the patient did not have any respiratory distress though cyanosis was present. Also I found cyanosis in her daughter. Therefore, I recommended to do complete blood count with blood film examination and hemoglobin electrophoresis as well as gave advice to consult with a hematologist.

\section{Differential Diagnosis}

Dr. Mohammad Mizanur Rahman (Hematologist): I received the patient at the Department of Hematology, Armed Forces Institute of Pathology, Dhaka cantonment, Bangladesh on 17th September, 2018 at 0900 hours. The patient was accompanied by her daughter. I took all relevant history and examined the patient systemically. On general examination, cyanosis was found in the tongue, lips and hands, anemia was absent, pulse $120 / \mathrm{min}$, blood pressure $120 / 65 \mathrm{~mm} \mathrm{Hg}$. All other parameters were within normal limits. Systemic examination revealed no abnormalities. I also reviewed the all investigations so far done and keeping in mind of the above diagnosis, I advised to do complete blood count with blood film examination, reticulocyte count, hemoglobin electrophoresis, blood urea, creatinine and BUN, serum LDH and electrolytes, G-6-PD assay and rapid screening filter paper test of the patient and her daughter and made the following differential diagnosis for cyanosis with the original diagnosis she presented.

\section{Methemoglobinemia}

Methemoglobinemia is defined as a condition in which there is an increased blood level of methemoglobin. Methemoglobin is a derivative of normal hemoglobin in which iron of the heme complex has been oxidized from the ferrous to the ferric form. It does not combine with oxygen and does not take part in oxygen transport.1 In normal red cells, methemoglobin is continually being formed by the auto-oxidation of hemoglobin but it is reduced as soon as it is formed; thus the concentration of methemoglobin in the red cell under normal conditions is less than one percent of the total hemoglobin. The reduction of methemoglobin is accomplished by the enzyme NADH-methemoglobin reductase in the presence of NADH. Methemoglobin lacks the capacity to carry oxygen and as a result methemoglobinemia causes symptoms and signs of hypoxia.2 Infants under 6 months of age are most commonly affected, although the common age range is $0-4$ months. Infants in this age group are at more risk of developing the signs and symptoms of methemoglobinemia because they have not mutated 


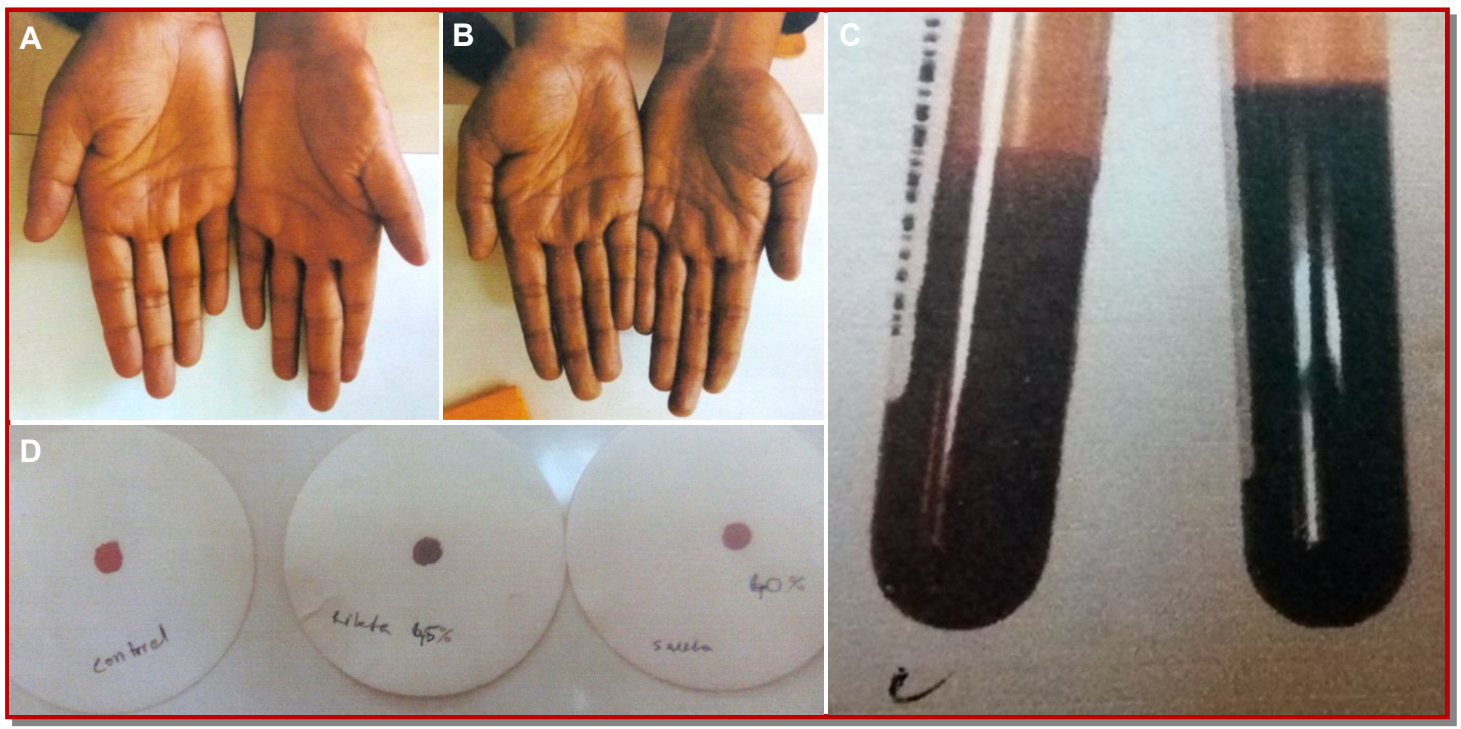

Figure 1: Patient's (A) and daughter's (B) hands showing cyanosis; Chocolate brown color of methemoglobinemia in control (C, left) and patient's (C, right) samples; Rapid screening filter paper test (D);

enough to produce methemoglobin reductase, an oxygen-carrying molecule. $\underline{3}$ Peoples who are using private water wells containing nitrates are more vulnerable to develop methemoglobinemia. 4 The link between blue baby syndrome in infants and high nitrate levels is well established for water exceeding the normal levels of $10 \mathrm{mg} / \mathrm{dL} . \underline{5}$ Breast feeding may maintain a protective level in exposed infants. 6 Methemoglobinemia is of two types: Toxic methemoglobinemia and hereditary methemoglobinemia. 7 Toxic methemoglobinemia may be due to drugs, occupational agents and household beaches. Drugs which may be responsible for methemoglobinemia are phenacetin, acetanilide, sulphonamides, sulphones, dapsone $\stackrel{8}{-}$, prilocane? primaquine and pamaquine, nitrites, nitrates and potassium chlorate. In red cells, the protective enzyme system normally present in apparently healthy individuals quickly reduce the methemoglobin back to hemoglobin and thereby maintain methemoglobin levels at less than one percent of total hemoglobin concentration. However, exposure to such oxidizing drugs and their metabolites may increase the concentration of methemoglobin up to a thousand fold, exhausting the protective enzyme system of red cells and lead to high methemoglobin level in blood. 10 Predominantly responsible methemoglobin reduction enzyme, NADH - cytochrome b5 reductase are present in low concentration in infants less than six months of age. Therefore, infants in this age group are more prone to develop methemoglobinemia when exposed to nitrates present in drinking water.11 Baby teething gel or sore throat lozenges containing benzocaine applied to the gums or throat of infants are also at risk of developing methemoglobinemia. 12 In industry, workers may develop methemoglobinemia when exposed to commonly used industrial agents such as nitrobenzene, trinitrobenzine and aniline which usually absorb through the respiratory tract or skin. 13 Household chemicals such as furniture and shoe polish containing nitrobenzene, marking ink, shoe dyes, colored crayons containing aniline, perfumes and flavoring essence are also capable of producing methemoglobinemia. $\underline{14}$ Hereditary methemoglobinemia occurs due to deficiency of $\mathrm{NADH}$ cytochrome b5 reductase in the red cells causing increased blood level of methemoglobin reducing oxygen-carrying capacity of blood. The patients with methemoglobin develop brown chocolate color arterial blood instead of normal bright red oxygen carrying arterial blood. Hereditary methemoglobinemia is an autosomal recessive disorder, therefore if only one parent carry this gene, the offspring will have normal colored skin but if both parents carry this gene, then $25 \%$ offspring have the probability of having signs and symptoms of hereditary methemoglobinemia. Methemoglobinemia may also arise due to deficiency of the enzyme pyruvate kinase, the cofactor for NADH cytochrome b5 reductase and glucose -6-phosphate dehydrogenase deficiency due to impaired production of NADPH. A number of variant hemoglobins may cause hereditary methemoglobinemia. Notable among these are hemoglobin $M$ and hemoglobin H. $\underline{15}$ Methemoglobinemia either acquired or hereditary can be treated by supplemental oxygen and methylene blue.16 Symptoms are proportional to the level of methemoglobin in blood. Methemoglobin level of 3 $-15 \%$, only develop slight discoloration of skin. Patient with methemoglobin level of $15-20 \%$ may be relatively asymptomatic except cyanosis Patients with methemoglobinemia of $25-50 \%$ usually presents with shortness of breath, cyanosis, mental status changes, headache, fatigue, exercise intoler- 
ance, dizziness. Methemoglobin level of 50 to $70 \%$ may develop abnormal cardiac rhythms, altered mental status, delirium, seizers, coma and profound acidosis. Patients with severe methemoglobinemia $(>70 \%)$ may succumb to death. 17 Methemoglobinemia due to oxidizing drugs rarely cause problems with oxygen delivery. However, severe cases (> 40\% methemoglobin) may be treated with intravenous methylene blue $1-2 \mathrm{mg} / \mathrm{kg}$. Ascorbic acid by mouth may also be used. 18 Methylene blue restores the iron in hemoglobin to its normal oxygen-carrying state by supplying an artificial electron acceptor (such as methylene blue or flavin) for NADPH methemoglobin reductase. Hereditary methemoglobinemia in whom methemoglobin level usually remain in low level may be treated by oral methylene blue daily. Vitamin C can sometimes reduce cyanosis associated with chronic methemoglobinemia. 19 This patient did not present with the symptoms and signs of moderate or severe methemoglobinemia. She only had cyanosis, no breathlessness, seizers and coma. Her daughter also presented with cyanosis like her as well as there was no history of taking any drugs or taking water containing nitrites or nitrates and household or occupational agents responsible for methemoglobinemia. Therefore, she might be a case of mild hereditary methemoglobinemia.

\section{Cyanotic heart disease}

Cyanotic heart disease is a group of congenital heart disease that occurs due to deoxygenated blood bypassing the lungs and entering the systemic circulation or mixer of oxygenated and deoxygenated blood entering the systemic circulation.20 Of the "five "Ts" of congenital heart disease tetralogy of Falot, transposition of great arteries, total anomalous pulmonary venous circulation, truncus and tricuspid valve abnormalities - the first and last are commonly associated with reduced pulmonary blood flow. Heart valve defects that cause cyanosis include: tricuspid valve may be absent or unable to open wide enough, pulmonary valve may be absent or unable to open wide, aortic valve unable to open enough. 21 In Bangladesh, congenital heart disease accounts for 25/1000 live births..22 Patients with cyanotic congenital heart disease usually presents with cyanosis - bluish discoloration of face, lips, hands and toes, clubbing, tachycardia, trachypnea, history of inadequate feeding, unusually large toes and finger nails. $\underline{23}$ Besides these clinical features, children with congenital cyanotic heart disease may present with growth retardation. In a study, it was observed that $23 \%$ children had moderate under weight and $77 \%$ had severe growth retardation. Growth retardation was more marked in cyanotic heart disease $(100 \%)$ than acyanotic heart disease (93\%). $\underline{24}$ Early detection of critical congenital heart disease allow the concerned physicians for timely appropriate management. Delayed or missed diagnosis may lead to acute cardiovascular collapse, acidosis and death. Bangladesh is well ahead in the managements of congenital heart defects with limited resources. Routine screening for CHD depends on mid-trimester anomaly scan. Fetal ultrasound is routinely performed and may detect fewer than $50 \%$ of cases of critical congenital heart disease. Echocardiography is an obligatory diagnostic tool but the cost is a severe limitation as a universal screening tool. However, it may give false positive result. 25 Before more than a decade, pulse oxymetry was used for detection of critical congenital heart disease with the principle that some degree of clinically undetectable hypoxemia is present in most forms of critical congenital heart disease. Children with arterial oxygen saturation of $80-90 \%$ may not have visible cyanosis and such cyanosis is particularly problematic in dark skinned baby. Pulse oxymetry is considered a vital sign equivalent in importance to pulse, respirations and blood pressure. Pulse oxymetry contributes significant role in the detection of CHD in neonates. 26 In this patient, presence of cyanosis is in favor of the diagnosis of cyanotic heart disease but age of the patient, absence of signs and symptoms of cyanotic heart disease are the points against the diagnosis of cyanotic heart disease.

\section{Chronic obstructive pulmonary disease}

Chronic obstructive pulmonary disease (COPD) is a type of obstructive lung disease characterized by long-term breathing difficulties and poor airflow. .27, 28 COPD comprises bronchial asthma, emphysema, chronic bronchitis and bronchectasis.29, 30 COPD affected about 174.5 million $(2.4 \%)$ of the world population. 11 People over the age of 40 are more commonly affected and there is no sex predilection. $\underline{29}$ Deaths from COPD are gradually increasing, from 2.4 million in 1990 to 3.2 million in

\begin{tabular}{|c|c|c|c|c|c|c|c|c|c|c|}
\hline \multicolumn{11}{|c|}{ Table II } \\
\hline \multicolumn{11}{|c|}{ Relevant hematological parameters of the patient and her daughter } \\
\hline & \multirow{2}{*}{$\begin{array}{l}\text { Hemoglobin } \\
(\mathrm{g} / \mathrm{dL})\end{array}$} & \multirow{2}{*}{$\begin{array}{l}\mathrm{MCV} \\
\text { (fL) }\end{array}$} & \multirow{2}{*}{$\begin{array}{l}\mathrm{MCH} \\
(\mathrm{pg})\end{array}$} & \multirow{2}{*}{$\begin{array}{l}\text { MCHC } \\
(\mathrm{g} / \mathrm{dL})\end{array}$} & \multirow{2}{*}{$\begin{array}{c}\text { WBC } \\
\left(\mathrm{X} 10^{9} / \mathrm{L}\right)\end{array}$} & \multirow{2}{*}{$\begin{array}{l}\text { Reticulo- } \\
\text { cyte }(\%)\end{array}$} & \multicolumn{4}{|c|}{ Hemoglobin electrophoresis } \\
\hline & & & & & & & $\mathrm{HbA}$ & $\mathrm{HbA}_{2}$ & $\mathrm{HBF}$ & $\mathrm{HbM}$ \\
\hline Patient & 13.6 & 99.7 & 35.1 & 35.1 & 9.5 & 1.7 & 57.5 & 3.8 & Nil & 38.7 (Boston) \\
\hline Daughter & 14.7 & 87.1 & 27.4 & 31.5 & 6.0 & 2.0 & $48.2(\mathrm{HbA}+\mathrm{HbM})$ & 0.5 & Nil & 46.1 (Saskaton) \\
\hline
\end{tabular}


2015.32,33 In developing countries, the death toll from COPD is more than $90 \%$ and it is expected that it will further increase because of higher smoking rates in developing world and an increasing number of aging population in many countries. $\underline{34}$

Factors responsible for the development of COPD: tobacco smoking, air pollution and genetics. 35 Poorly vented heating and cooking fires are the main factors in developing countries for air pollution.29 Long-term exposure to these irritants causes an inflammatory response in the lungs, resulting in narrowing of the small airways and breakdown of lung tissue. .36 Most patients with COPD presents with shortness of breath, prolonged cough and sputum production. The shortness of breath is getting worse on exertion on a prolonged duration and worsens over time. $\frac{37}{4}$ An acute exacerbation of COPD is accompanied by increased shortness of breath, increased sputum production, change in color of sputum from clear to green or yellow. Patients with exacerbation of COPD may present with increased work of breathing such as tachypnea, tachycardia, active use of neck muscles and cyanosis. $\underline{38}$

Diagnosis of COPD should be suspected in any individual over the age of 40 presented with shortness of breath, chronic cough, frequent sputum production and history of the presence of risk factors. 39 Diagnostic testing includes a long list of investigations. Among these are pulse oximetry to assess the degree of hypoxemia, X-chest, ECG, basic blood tests, arterial blood gas measurement, cardiac biomarkers, D-dimer, lower extremity ultrasound and CT angiography. Spirometry is then used to confirm the diagnosis. $\underline{40}$ No cure for COPD is known but symptoms can be treatable and its progression can be delayed. $\underline{41}$ The major goals of treatment are to reduce risk factors, manage stable COPD, prevent and treat acute exacerbation and manage associated illness. $\underline{36}$ Cessation of smoking and providing supplemental oxygen are the important measures to reduce the mortality. $\underline{42}$ Risk of death reduces by $20 \%$ by stopping the smoking. Other measures such as influenza vaccination once in a year, pneumococcal vaccination once every five years and reduction of exposure to environmental pollution reduce the risk of acute exacerbation and death. $\underline{35}$ Use of morphine may reduce the feelings of shortness of breath in advanced cases of COPD. $\underline{43}$ Age of the patient and presence of cyanosis is in favor of the diagnosis of COPD but absence of breathlessness, chronic cough and sputum production as well as family history of the presence of cyanosis and absence of smoking disfavors the diagnosis of COPD.

\section{Raynaud syndrome}

Raynaud syndrome, also known as Raynaud phenomenon is a condition in which spasms of arteries cause episodes of reduced blood flow.
Usually fingers and less commonly toes are affected. The nose, ears and lips may be affected rarely.44 Raynaud syndrome usually cause the affected part initially white and then turn into blue. Numbness or pain may occur and as blood flow returns normal, the affected area turns red. The episodes usually lasts for minutes but in some occasion several hours. $\underline{45}$ There are two types of Raynaud disease: Primary or idiopathic and secondary. Primary Raynaud or Raynaud disease is diagnosed if the symptoms occur by themselves and in association with other diseases. Some refer primary Raynaud as "allergic to coldness". It usually develops in young women in their teens and early adulthood. Although specific genes have not yet to be identified but it is thought that primary Raynaud is partly hereditary. $\underline{46}$ Frequency of attack may be increased on smoking and estrogen, caffeine and non-selective beta blockers are the aggravating factors. Patients with Raynaud's disease are more likely to have migraine and angina. $\underline{4}$ Raynaud's phenomenon or secondary Raynaud may occur in association with several diseases such as connective tissue disease, eating disorders, obstructive disorders, drugs, occupations and others. Raynaud can backer these diseases by periods of more than 20 years in some cases. When Raynaud's phenomenon is limited to one hand or one toe, it is called unilateral Raynaud's. This is an uncommon form and it is always secondary to local or regional vascular disease. It commonly progresses within several years to affect other limbs as the vascular disease progresses. $\underline{47}$ Raynaud's occurs in about $4 \%$ of peoples. Females are more frequently affected than males by primary Raynaud's and typically occurs in between 15 to 30 years of age. Secondary forms usually occurs in older subjects. $\underline{44}$ Patients with Raynaud's usually presents with pain within the extremities, discoloration (paleness) and sensation of cold and numbness. Raynaud's patients may become serious if placed into a cold climate. The blood supply to the fingers or toes and in some cases the nose or earlobes is markedly reduced when exposed to cold temperatures, as a result the affected skin becomes pale or white and cold and numb. Such attacks are episodic and after the diminishment of such episode or the area is warmed, the blood flow returns and the skin color first turns red and then back to normal. All these color changes are observed in classic Raynaud's. In pregnancy, this sign normally disappears due to hyperdynamic blood flow. $\underline{48}$ Diagnosis of Raynaud's phenomenon needs a multiple sets of diagnostic tests, ranging from routine laboratory investigations to imaging studies. $\underline{49-52}$ Secondary Raynaud's may be managed by treating the underlying etiology but to ameliorate the signs and symptoms of primary Raynaud's, the triggering factors such as cold, emotional and environmental stress, vibrations and repetitive motions, smoking and sympathomimetic drugs should be avoided. $\underline{53}$ 
Gender, skin discolora-tion of the extremities and pain favors the diagnosis of Raynaud's phenomenon but absence of aggrava-ting factors for pain and numbness, presence of family history of cyanosis are the points against Raynaud's phenomenon.

\section{Discussion}

Dr. Rahman: Considering the patient's and her daughter's phenotypic features as well as the history provided by the patient and after analyzing the differential diagnosis, the most likely diagnosis might be methemoglobinemia. In this case, methemoglobinemia does not fulfill the criteria of either acquired or hereditary (NADH cytochrome b5 reductase deficiency) form because the history could not reveal any exposure to toxic, occupational or household agents and as patient did not have any signs and symptoms of breathlessness or any other symptoms of methemoglobinemia other than cyanosis. Therefore, methemoglobinemia in this patient and her family members might be due to abnormal hemoglobin $M$ or glucose-6-phosphate dehydrogenase deficiency. G6PD deficiency is an Xlinked recessive disorder where males are usually affected, so this condition is excluded as both sexes of this family have been affected and presented with only cyanosis. Moreover, cyanosis is not a common finding in G6PD deficiency and patient should have anemia and other features of hemolysis in G6PD deficiency. Laboratory investigations revealed no features of hemolysis, normal G6PD and LDH level as well as normal reticulocyte count. Hence, abnormal hemoglobin $\mathrm{M}$ might be the most likely cause of methemoglobinemia in this patient and her family members. To find out the abnormal hemoglobins, I advised to perform capillary hemoglobin electrophoresis (Figure 2). The relevant hematological parameters of the patient and her daughter are shown in Table I. After one week I got the results of hemoglobin electrophoresis which unveiled the presence of hemoglobin $\mathrm{M}$ Boston in the patient and hemoglobin M Boston and hemoglobin $M$ Saskatoon in her daughter, almost confirming that the presence of such hemoglobin $\mathrm{M}$ in their blood is responsible for development of cyanosis in this family and methemoglobinemia is due to hemoglobin $\mathrm{M}$ and hemoglobin M Saskatoon in this patients and her daughter.

Dr. Sarfin (Resident, Clinical Pathology): What are the variants of hemoglobin $\mathrm{M}$ ?

Dr. Monir (Resident, Hematology): Hemoglobin M isolated from different families affected by hemoglobin $\mathrm{M}$ disease is heterogeneous. These variants have been designated as $\mathrm{M}_{\text {Boston }}\left(\mathrm{M}_{\mathrm{B}}\right), 54,55$ M Milwakuae $1 \quad\left(\mathrm{M}_{1}\right), \quad \mathrm{M}_{\text {Milwakuae } 2}\left(\mathrm{M}_{2}\right), \underline{56,57} \mathrm{M}_{\text {Saskatoon }}$ $\left(\mathrm{M}_{\mathrm{S}}\right), \underline{55} \mathrm{M}_{\text {leipzig }}\left(\mathrm{M}_{\mathrm{L}}\right) \underline{58}, \mathrm{M}_{\text {Iwata }}\left(\mathrm{M}_{\mathrm{I}}\right), \underline{\underline{59}} \mathrm{M}_{\text {Chicago }}\left(\mathrm{M}_{\mathrm{Ch}}\right) . \underline{60}$ In our case, the patient has been carrying $\mathrm{HbM}_{\mathrm{B}}$ and the daughter carrying $\mathrm{HbM}_{\mathrm{B}}$ and $\mathrm{HbM}_{\mathrm{S}}$.

Dr. Shihab (Resident, Clinical Pathology): You have described seven hemoglobin $\mathrm{M}$ variants. Is there any other hemoglobin $\mathrm{M}$ variant?

Dr. Maruf (Anesthesiologist): In some literature, twelve known hemoglobin $M$ variants have been cited. Among these, three are alpha-chain (hemoglobin M Iwate, hemoglobin M Boston, hemoglobin M Yantai), three beta-chain (hemoglobin M Saskatoon, hemoglobin M Milwaukee, hemoglobin M Hyde Park) and six gamma chain (Hb FM Osaka, $\mathrm{Hb}$ FM Fort Ripley, $\mathrm{Hb}$ FM Circleville, $\mathrm{HbF}$ Cincinnati, HbFM Toms River, HbFM Viseu) variants.

Dr. Mehedi (Resident, Clinical Pathology): What type of disease produced by hemoglobin M?

Dr. Shahid (Resident, Hematology): Hemoglobin M is an abnormal hemoglobin which produce a disease called hemoglobin $\mathrm{M}$ disease. $\underline{63}$

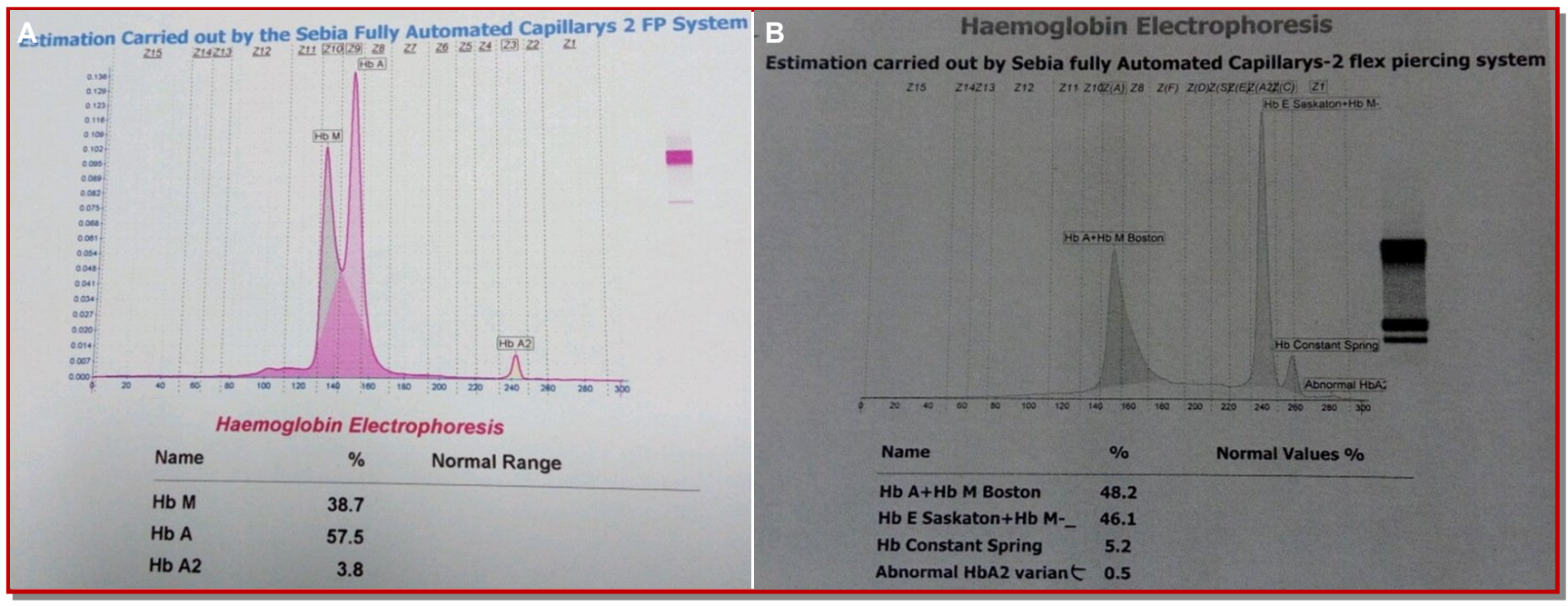

Figure 2: Capillary hemoglobin pattern of the patient (A) and daughter (B) 
Dr. Alam (Resident, Clinical Pathology): Is hemoglobin $\mathrm{M}$ disease hereditary? If so, what is the mode of inheritance?

Dr. Mreenal (Resident, Biochemistry): Yes, hemoglobin $\mathrm{M}$ disease is a hereditary disorder, e.g., one type of hemoglobinopathies. The mode of inheritance is autosomal dominant where the transmission is vertical and both sexes are affected.64 In this case also many of the family members of this family such as offspring (daughter) and grandson were found affected.

Dr. Imana (Resident, Microbiology): What is the molecular basis of hemoglobin $\mathrm{M}$ formation?

Dr. Rahman (Hematologist): In most of the variants of hemoglobin $\mathrm{M}$, tyrosine replaces histidine residue, which binds heme to globin. This replacement displaces the heme moiety and permits oxidation of the iron to the ferric state. As a result, hemoglobin $\mathrm{M}$ is more resistant to reduction by the methemoglobin reduction enzyme (cytochrome b5 reductase) resulting in a functionally impaired hemoglobin with decreased oxygen affinity. There are three phenotypic varieties of hemoglobin $M$ depending on the globin gene (alpha, beta, gamma) affected: alpha-chain variants cause neonatal cyanosis that is persistent; beta-chain variants do not cause cyanosis until several months after birth when the level of $\mathrm{HbF}$ has decreased; gamma-chain variants cause transient neonatal cyanosis that disappears once the level of $\mathrm{HbF}$ decreases. $\underline{65-67}$

Dr. Mahin (Resident, Histopathology): In your patient, what was the phenotypic variant?

Dr. Shahid (Resident, Hematology): Without molecular analysis of globin chain, it is difficult to say from which variants (alpha, beta or gamma) the patient and her family members have been affected. But after analyzing the history (where she told that she had bluish coloration of lips, hands and tongue from childhood) and physical findings, it can be assumed that this family might be affected by betachain variant.

Dr. Golam Rabbani (Hematologist): As per the history, the patient had cardiomegaly, $\mathrm{SO}_{2}$ was $55 \%$ and arterial blood gas analysis was normal. How will you explain these with hemoglobin $\mathrm{M}$ disease?

Dr Giti (Hematologist): X-ray chest showed cardiomegaly but later it was excluded by echocardiography. So, cyanosis in this family was not either due to cardiac or respiratory cause. Pulse oxymetry showed $\mathrm{SO}_{2}$ was $55 \%$. But it was observed that in presence of methemoglobinemia, pulse oxymetry and co-oximetry produce erroneous result.68

Dr. Umme Hani (Resident, Histopathology): What is the mechanism of methemoglobin formation in hemoglobin $\mathrm{M}$ disease?

Dr. Monir (Resident, Hematologist): In hemoglobin M, tyrosine has been substituted for either the proximal or the distal histidine. This results in reduced capacity of the enzymatic machinery of the erythrocyte to effectively and efficiently reduce the iron to the divalent form and thus predisposes the formation of methemoglobin. $\underline{69}$

Dr. Sifat (Resident, Hematology): What features have you found to diagnose that this methemoglobinemia is due to hemoglobin $\mathrm{M}$ disease?

Dr. Mreenal (Resident, Biochemistry): A number of features favors the diagnosis of methemoglobinemia due to hemoglobin $M$ disease: Absence of history of exposure to agents causing methemoglobinemia (excludes acquired methemoglobinemia); absence of severe developmental abnormalities, mental retardation and neurologic impairment (excludes type II hereditary methemoglobinemia); A mild confusion was in mind in differentiating between type I hereditary methemoglobinemia and hemoglobin $\mathrm{M}$ disease. In both cases, there is only chronic low-grade cyanosis. $\underline{70}$ In this case positive family history of cyanosis from childhood and capillary hemoglobin electrophoresis makes the way easy to differentiate from type I hereditary methemoglobi-nemia. Moreover, cyanosis in successive generations (present in this family) suggests the presence of hemoglobin $\mathrm{M}$ which was present in this case. On the other hand, normal parents and possibly affected siblings indicate the presence of $\mathrm{NADH}$ cytochrome b5 reductase deficiency which was not found in this case. .71

Dr. Sarwar (Medical Specialist): How does a patient with methemoglobinemia presents?

Dr. Shahid (Resident, Hematology): Presentation due to methemoglobinemia depends on methemoglobin fraction in blood. Normally methemoglobin fraction is about $1 \%(0-3 \%)$. Patients with methemoglobin levels of $3-15 \%$, a slight discoloration (e.g., pale, gray, blue) of the skin may be present. Patients with methemoglobin levels of $15-20 \%$ may be relatively asymptomatic except cyanosis. Patients with methemoglobin levels of $25-50 \%$ may have headache, lightheadedness, weakness, palpitation and exertional dyspnea. Patients with methemoglobin levels of more than $70 \%$ may cause death. 72 In this case, we did rapid filter paper test which revealed 45 and $40 \%$ methemoglobin in patient's daughter and the patient respectively (Figure 2) and also comparison was done between patient's blood and normal control blood taken in evacuated tubes (Figure 2) which revealed chocolate brown color blood in this patient.

Dr. Rukun (Neurosurgeon): If I consider this patient is a case of sulfhemoglobinemia, how will you explain it?

Dr. Rahman (Hematologist): Sulfhemoglobinemia is a condition in which sulfur molecule is incorporated into the heme moiety. Usually a number of drugs 
such as sulfonamides and phenacetin, that produce methemoglobinemia, can also produce sulfhemoglobinemia. $\frac{73}{}$ Symptoms tend to be milder than in patients with methemoglobinemia. The diagnosis is confirmed by elevated levels of sulfhemoglobin by either spectrophotometry or gas chromatography-mass spectrometry. $\underline{74}$

Dr. Husnuzzaman (Resident, Biochemistry): How will you treat the patient with methemoglobinemia due to hemoglobin $\mathrm{M}$ disease?

Dr. Shahid (Resident, Hematology): No treatment is required unless cause hemolysis because hemoglobin $\mathrm{M}$ disease does not respond to ascorbic acid or methylene blue. $\underline{75}$

Dr. Fatema (Resident, Histopathology): As per genetic rule, all family members should have same hemoglobin $\mathrm{M}$. Why have there been differences of hemoglobin $\mathrm{M}$ in between mother and her daughter.

Dr. Giti (Hematologist): Molecular basis of a rare genetic disorder like hemoglobin $\mathrm{M}$ is not identical in each case. In this disorder, an internal complex forms between the heme iron and reactive side chain of an amino acid. Normally such a complex does not form because the normal amino acid sequence along the helical structure of the polypeptide chain prevents such "internal complexing"..$\underline{6}$

Dr. Mehedi (Resident, Clinical pathology): What is the prognosis of hereditary methemoglobinemia?

Dr. Morshed Rashid (Public Health Specialist): Hereditary methemoglobinemia due to hemoglobin $\mathrm{M}$ is a benign condition and counseling is good enough to alleviate the anxiety and cosmetic effects of persistent cyanosis. The prognosis of mild cases of hereditary methemoglobinemia due to NADH cytochrome b5 reductase deficiency is very favorable; however, in severe cases, the prognosis is determined by the degree of anoxic end-organ damage. .77

\section{Final Diagnosis}

Hemoglobin $\mathrm{M}$ disease with cervical nerve root com -pression with hypertension with diabetes mellitus

\section{References}

1. Darling RC, Roughton FJW. The effect of methemoglobin on the equilibrium between oxygen and hemoglobin. Am J Physiol. 1942; 137: 56-68.

2. Saxena R, Pati HR, Mahanpatra M. de Gruchy's Clinical hematology in medical practice. In: Saxena R, Pati HR, Mahanpatra M (eds). 6th ed. New Delhi. Wiley India Pvt. Ltd., 2013, pp 143-44.
3. Richard AM, Diaz JH, Kaye AD. Reexamining the risks of drinking water nitrates on public health. Ochesner J. 2014; 14: 392-98.

4. Manassaram DM, Backer LC, Moll DM. A review of nitrates in drinking water: Maternal exposure and reproductive and developmental outcomes. Environ Health Perspect. 2006; 114: 320-27.

5. Nitrate and nitrite in drinking-water. WHO Press, 2011.

6. Pollock J. Long-term associations with infant feeding in a clinically advantaged population of babies. Develop Med Child Neurol. 1994; 36: 429-40.

7. Ash-Bernal R, Wise R, Wright SM. Acquired methhemoglobinemia: A retrospective series of 138 cases at two teaching hospitals. Medicine 2004; 83: $265-73$.

8. Zosel A, Rychter K, Leikin JB. Dapsone-induced methemoglobinemia: Case report and literature review. Am J Ther. 2007; 14: 585-87.

9. Adams V, Marly J, McCarroll C. Prilocaine induced methemoglobinemia in a medically compromised patient. Was this an inevitable consequence of the dose administered? Br Dent J. 2007; 203: 585-87.

10. Elebute MO, Kesse-Adu R. Acquired hemolytic anemia. In: Hffbrand AV, Higgs DR, Keeling DM, Mehta AB (eds). $7^{\text {th }}$ ed. Oxford, John Wiley and Sons Ltd, 2016, pp 153-54.

11. Basic information about nitrates in drinking water. United states environmental protection agency, 2013.

12. FDA drug safety communication: Reports of a rare but serious and potentially fatal adverse effect with the use of over-the-counter (OTC) benzocaine gels and liquids applied to the gums or mouth. US food and drug administration, 2011.

13. Lee $\mathrm{CH}$, Kim $\mathrm{SH}$, Kwon DH, Jang $\mathrm{KH}$, Chung $\mathrm{YH}$, Moon JD. Two cases of methemoglobinemia induced by the exposure to nitrobenzene and aniline. Ann Occup Environ Med. 2013; 25: 31.

14. Messmer AS, Nickel $\mathrm{CH}$, Bareiss D. p-Chloroaniline poisoning causing methemoglobinemia: A case report and review of literature. Case Rep Emerg Med. 2015; 2015: 208732.

15. Da-Silva SS, Sajan IS, Underwood JP 3rd. Congenital methemoglobinemia: A rare case of cyanosis in the newborn- a case report. Pediatrics 2003; 112: 158 -61 .

16. Gillman PK. Methylene blue implicated in potentially fatal serotonin toxicity. Anesthesia 2006; 61: 1013-14.

17. Yusim Y, Livingstone D, Sidi A. Blue dyes, blue people: The systemic effects of blue dyes when administered via different routes. J Clin Anesth. 2007; 19: 315-21.

18. do Nascimento TS, Pereira RO, de Mello HL, Costa J. Methemoglobinemia: From diagnosis to treat- 
ment. Rev Bras Anestesiol. 2008; 58: 651-64.

19. Yubisui T, Takeshita M, Yoneyama Y. Reduction of methemoglobin through flavin at the physiological concentration by NADPH-flavin reductase of human erythrocytes. J Biochem. 1980; 87: 1715-20.

20. Waldman JD, Wernly JA. Cyanotic congenital heart disease with decreased pulmonary blood flow in children. Pediatr Clin North Am. 1999; 46: 385-404.

21. Bernstein D. Cyanotic congenital heart disease: Evaluation of the critically ill neonate with cyanosis and respiratory distress. In: Nelson Textbook of pediatrics. Kliegman RM, Stanton BF, St. Geme JW, Schor NF (eds). 20 th ed. Philadelphia, Elsevier, 2016, p 429.

22. Sharmin LS, Haque MA, Bari MI, Ali MA. Pattern and clinical profile of congenital heart disease in a teaching hospital. TAJ. 2008; 21: 58-62.

23. Mollah MAH, Begum NA, Islam MN, Mahmud RS, Haq MA, Nahar N, Rashid MA. Clinical profile of congenital heart disease (CHD): An analysis of 218 cases. Bangladesh Heart J. 2002; 17: 62-67.

24. Chowdhury F, Hoque M, Ali MM, Haossain MA. Comparison of growth in children with cyanotic and acyanotic congenital heart disease in a tertiary care hospital. J Bangladesh Coll Phys Surg. 2018; 36: 64-69.

25. Sen SS, Mosleh T, Jahan I, Dey SK. Pulse oximetry screening in newborn for early detection for critical congenital heart disease: A review. Bangladesh J Child Health. 2015; 39: 148-53.

26. Koppel RI, Druschel CM, Carter T, Goldberg BE, Mehta PN, Talwar R, Bierman FZ. Effectiveness of pulse oxymetry for congenital heart disease in asymptomatic newborns. Pediatrics 2003; 111: 451-55.

27. Algusti AG. Definition and overview, Global strategy for the diagnosis, management and prevention of COPD. Global initiative for chronic obstructive lung disease (GOLD), 2017; 3: 6-17.

28. Roversi S, Corbetta L, Clini E. GOLD 2017 recommendations for COPD patients: Towards a more personalized approach. COPD Res Practice. 2017; 3: 5.

29. Chronic obstructive pulmonary disease (COPD), Fact sheet N0315; WHO, 2015.

30. Craig JA. Ferri's netter patient advisor. $2^{\text {nd }}$ ed. Saunders, 2012, p 913.

31. GBD 2015 disease and injury incidence and prevalence collaborators. Global, regional and national incidence, prevalence and years lived with disability for 310 diseases and injuries, 1990-2015: A systematic analysis for the global burden of disease study 2015. Lancet 2016; 388: 1545-602.

32. GBD 2015 mortality and causes of death collaborators. Global, regional and national life expectancy, all-cause mortality and cause-specific mortality for 249 causes of death, 1980-2015: A systematic analysis for the global burden of disease study 2015. Lancet 2016; 388: 1459-544.

33. GBD 2014 mortality and causes of death collaborators. Global, regional and national age-specific all-cause and cause specific mortality for 240 causes of death, 1990-2013: A systemic analysis for the global burden of disease study 2013. Lancet 2015; 385: 117-71.

34. Mathers CD, Loncar D. Projection of global mortality and burden of disease from 2002 to 2030. PLoS Med. 2006; 3: e442.

35. Decramer M, Janssens W, Miravitlles M. Chronic obstructive pulmonary disease. Lancet 2012; 379: 1341-51.

36. Vestbo J, Hurd SS, Agustí AG, Jones PW, Vogelmeier C, Anzueto A, Barnes PJ, Fabbri LM, Martinez FJ, Nishimura M, Stockley RA. Global strategy for the diagnosis, management and prevention of chronic obstructive pulmonary disease: GOLD executive summary. Am J Respir Crit Care Med. 2013; 176: 532-55.

37. Vestbo J. Diagnosis and assessment. Global strategy for the diagnosis, management and prevention of chronic obstructive pulmonary disease. Global Initiative Chronic Obstructive Lung Dis. 2013; 9-17.

38. Gruber P, Swadron S, DeBlieux P, Nelson B. The acute presentation of chronic obstructive pulmonary disease in the emergency department: A challenging oxymoron. Emerg Med Pract. 2008; 10: 1-27.

39. National institute for health and clinical excellence. Clinical guideline 101: Chronic obstructive pulmonary disease, 2010.

40. Qaseem A, Wilt TJ, Weinberger SE, Hariania NA, Criner G, van der Molen T, Marciniuk DD, Denberg $T$, Schünemann $H$, Wedzicha W, MacDonald R, Shekelle P. Diagnosis and management of stable chronic obstructive pulmonary disease: A clinical practice guideline update from the American college of physicians, American college of chest physicians, American thoracic society and European respiratory society. Ann Intern Med. 2011; 155: 179-91.

41. Vestbo J, Hurd SS, Agusti AG, Jones PW, Vogelmeier C, Anzueto A, Barnes PJ, Fabbri LM, Martinez FJ, Nishimura M, Stockley RA, Sin DD, Rodriguez-Roisin R. Global strategy for the diagnosis, management and prevention of chronic obstructive pulmonary disease: Gold executive summary. Am J Respir Crit Care Med. 2013; 187: 347-65.

42. Drummond MB, Dasenbrook EC, Pitz MW, Murphy DJ, Fan E. Inhaled corticosteroids in patients with stable chronic obstructive pulmonary disease: A systematic review and meta-analysis. JAMA. 2008; 300: 2407-16.

43. Carlucci A, Guerrieri A, Nava S. Palliative care in 
COPD patients: Is it only an end-of-life issue? Eur Respir Rev. 2012; 21: 347-54.

44. Wigley FM, Flavahan NA. Raynuad's Phenomenon. N Engl J Med. 2016; 375: 556-65.

45. What are the signs and symptoms of Raynaud's? NHLBI, 2014.

46. Pistorius MA, Planchon B, Schott JJ, Lemarec H. Hereditary and genetic aspect of Raynaud's disease. J Mal Vasc. 2006; 31: 10-15.

47. Priollet P. Raynaud's phenomenon: Diagnostic and treatment study. Rev Prat. 1998; 48: 1659-64.

48. Holmen OL, Backe B. An underdiagnosed cause of nipple pain presented on a camera phone. BMJ. 2009; 339: b2553.

49. Brennan P, Silman A, Black C, Bernstein R, Coppock J, Maddison P, Sheeran T, Stevens C, Wollheim F. Validity and reliability of three methods used in the diagnosis of Raynaud's phenomenon. The UK Scleroderma study group. $\mathrm{Br}$ J Rheumatol. 1993; 32: 357-61.

50. Wigley FM. Clinical practice, Raynaud's phenomenon. N Engl J Med. 2002; 347: 1001-08.

51. LeRoy EC, Medsger TA Jr. Raynaud's phenomenon: A proposal for classification. Clin Exp Rheumatol. 1992; 10: 485-88.

52. Maricq HR, Weinrich MC. Diagnosis of Raynaud's phenomenon assisted by color charts. J Rheumatol. 1998; 15: 454-59.

53. Mikuls TR, Canella AC, Moore GF, Erickson AR, Thiele GM, O'Dell JR. Connective tissue disease. Rheumatology. London, Manson Publishing, 2013, p 117.

54. Gerald PS. The electrophoretic and spectroscopic characterization of HbM. Blood 1958; 13: 936-49.

55. Gerald PS, George P. Second spectroscopically abnormal methemoglobin associated with hereditary cyanosis. Science 1959; 129: 393-94.

56. Pisciotta AV, Ebbe SN, Hinz JE. Clinical and laboratory features of two variants of methemoglobin disease. J Lab Clin Med. 1959; 54: 73-87.

57. Betke K, Groschner E, Bock K. Properties of a further variant of hemoglobin. Nature 1960; 188: 864.

58. Shibata F, Tamura A, Iuchi I, Takahashi H. Hemoglobin $\mathrm{M}_{1}$ : Demonstration of a new abnormal hemoglobin and hereditary nigremia. Act Hemat Jap. 1960; 23: 96-105.

59. Gerald PS, Efron ML. Chemical studies of several varieties of HbM. Proc Natl Acad Sci USA. 1961; 47: 1758-67.

60. Josephon AM, Weinstein HG, Yakulis VJ, Singer L, Heller P. A new variant of hemoglobin $M$ disease:

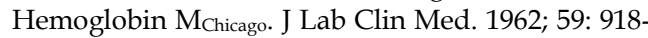
25.
61. Sun Y, Wang P, Li Y, Jiao F, Li Z, Ma Y, Li W, Xie S. Familial congenital cyanosis caused by $\mathrm{HbM}$ (Yantai). Gent Mol Biol. 2010; 33: 445-48.

62. Agarwal N, Nagel RL, Prchal JT. Dyshemoglobinemias. In: Disorders of hemoglobin: Genetics, pathophysiology and clinical management. $2^{\text {nd }}$ ed. London, Cambridge University Press, 2009, p 607.

63. Gibson QH. Reduction of methemoglobin in red cells and studies on cause of idiopathic methemoglobinemia. Biochem J. 1948; 42: 13-26.

64. Conway R, Browne P, O'Connell P. An unusual cause of methemoglobinemia. Iran Med J. 2009; 102: 184.

65. Mansouri A, Lurie AA. Concise review: Methemoglobinemia. Am J Hematol. 1993; 42: 7-12.

66. Gebara BM, Goetting MG. Life-threatening methemoglobinemia in infants with diarrhea and acidosis. Clin Pediatr (Phila). 1994; 33: 370-73.

67. Bento C, Magalhães Maia T, Carvalhais I, Moita F, Abreu G, Relvas L, Pereira A, Farela Neves J, Ribeiro ML. Transient neonatal cyanosis associated with a new $\mathrm{HbF}$ variant: $\mathrm{HbF}$ Viseu. J Pediatr Hematol Oncol. 2013; 35: e77-80.

68. Bruns CM, Thet LA, Woodson RD, Schultz J, Hla KM. Hemoglobinopathy case finding by pulse oxymetry. Am J Hematol. 2003; 74: 142-43.

69. Rahman HU. Methemoglobinemia. West J Med. 2001; 175: 193-96.

70. Worster-Drought C, White JC, Sargent F. Familial, idiopathic methemoglobinemia associated with mental deficiency and neurologic abnormalities. $\mathrm{Br}$ Med J. 1953; 2: 114-18.

71. Beutler E. Methemoglobinemia and other causes of cyanosis. In: Williams Hematology. Beutler E, Lichtman MA, Coller BS, Hipps TJ (eds). $5^{\text {th }}$ ed. New York, McGraw-Hill, 1994, pp 654-62.

72. Griffy RT, Brown DM, Nadel ES. Cyanosis. J Emerg Med. 2000; 18: 369-71.

73. Finch CA. Methemoglobin and sulfhemoglobin. N Engl J Med. 1984; 239: 470-78.

74. Demedts P, Wauters A, Watelle M, Neels H. Pitfalls in discriminating sulfhemoglobinemia from methemoglobinemia. Clin Chem. 1997; 43: 1098-99.

75. Bolyai JZ, Smith RP, Gray CT. Ascorbic acid and chemically induced methemoglobinemias. Toxicol Appl Pharmacol. 1972; 21: 176-85.

76. Gerald PS. The hereditary methemoglobinemias. In: Stanbury JB, Wyngaarden JB, Fredrickson DS (eds). The metabolic basis of inherited disease. New York, Mcgraw-Hill Book Company, 1960, pp 1068-85.

77. Heller P, Weinstein HG, Yakulis VJ, Rosenthal IM. Hemoglobin M Kankakee, a new variant of hemoglobin M. Blood 1962; 20: 287-301. 